\title{
KOMERCIJALNI FM RADIO U KONTEKSTU HRVATSKE MEDIJSKE POLITIKE
}

\section{Marina Mučalo}

PREGLEDNI RAD / DOI: https://doi.org/10.20901/ms.11.21.5 / PRIMLJENO: 27.2.2020.

SAŽETAK Komercijalni privatni radiji dominiraju hrvatskim radijskim krajolikom. Razvijali su se od sredine 90-ih godina, od čega se posljednjih 15 godina sustavno financiraju javnim sredstvima iz Fonda za poticanje pluralizma i raznovrsnosti elektroničkih medija. Rad problematizira hrvatsku medijsku politiku koja je proteklih godina u cijelosti zanemarila razvoj neprofitne i javne radiodifuzije, prepuštajući medijski razvoj zemlje tržišnim instrumentima i komercijalnim sadržajima. Recentna istraživanja pokazuju da se ta vrsta radijskih programa doživljava kao jednolična glazbena kulisa koja gubi povjerenje slušatelja. Rad otvara pitanje daljnjeg razvoja hrvatskoga medijskog sustava pri čemu istaknutu ulogu imaju institucije koje su odgovorne za njegovo oblikovanje.

\section{KLJUČNE RIJEČI}

KOMERCIJALNI FM RADIO, MEDIJSKI SUSTAV, MEDIJSKA POLITIKA, HRVATSKA

Bilješka o autorici

Marina Mučalo :: Fakultet političkih znanosti Sveučilišta u Zagrebu :: marina.mucalo@fpzg.hr 


\section{UVOD}

Osamostaljenje Republike Hrvatske donijelo je oštar zaokret prema višestranačju, tržišnom gospodarstvu i poduzetništvu, pa ni radijski medij nije ostao po strani. Budućnost se činila gospodarski stabilna i novi medijski poduzetnici planirali su prihodovati od oglašavanja roba i usluga u svojim programima. Posebnu dodanu vrijednost činila je dugogodišnja navika slušanja radija koja se tijekom Domovinskog rata samo dodatno učvrstila.

Međutim, regulacija medijskog okoliša, u kojem je trebalo dominirati privatno vlasništvo nad medijima, zahtijevala je više od dobre volje. Naime, punih 50 godina u Hrvatskoj nije bilo radija u privatnom vlasništvu, a kamoli komercijalnog usmjerenja. Usprkos gotovo stotinu godina radijske tradicije u Hrvatskoj, pred ondašnjom izvršnom vlašću stajao je zapravo nepoznat zadatak.

Devedesete godine 20. stoljeća u kontekstu uspostave domaćega medijskog tržišta najispravnije je ocijeniti kao „prvobitnu akumulaciju radijskog kapitala“ (Mučalo, 2010: 321). Odvijala se kroz privatizaciju postojećih i osnivanje novih radija, rasprave o politički „podobnim“ i „nepodobnim“ koncesionarima, (ne)transparentnost vlasničkih struktura i sve glasnijim zahtjevima za dijelom HRT-ove pristojbe. Osobito snažno nametalo se pitanje aktera i zakona kojima je trebala započeti era privatnih medija u Hrvatskoj, od vlasničkih struktura preko uvjeta za dobivanje koncesije do tehničko-tehnoloških predispozicija. I na kraju, ali ne manje važno, rokova, pa i način formiranja cijene toga poduzetničkog pothvata.

Nagla liberalizacija medijskog tržišta oslonila se na ekonomske kategorije i pravila. Budući da je privatni komercijalni radijski sektor in spe trebao prihodovati isključivo od komercijalnih usluga, poseban status dobilo je oglašavanje, a posredno i oglašivači.

Uvođenje tržišnih pravila prvi su osjetili novinari. Novinarka Jasmina Popović o tomu piše:

Proteklih deset godina bili smo svjedoci raspada jednog etabliranog, čvrstog medijskog sustava koji je kontrolirala država i nastanka novih, ponekad stvorenih preko noći, većih ili manjih medijskih kuća, koje su donijele svoja pravila ponašanja. To je rezultiralo kaosom i među vlasnicima i među novinarima. Vlasnik medija je mogao postati svatko tko je imao novca.[...] Stoga, ako možemo govoriti o manjem strahu od politike, onda moramo govoriti o većem strahu od vlasnika. Mislim da je taj strah presudan za nekoliko tisuća novinara. (Popović, 2000:130).

Sandra Bašić Hrvatin i Brankica Petković (2014: 13) tu pojavu opisuju kao „transformaciju novinarstva iz 'četvrte sile' u najunosniju sporednu djelatnost reklamne industrije i industrije političke komunikacije".

Medijska politika samostalne Republike Hrvatske otpočela je onog trenutka kad je određen smjer kojim će se kretati uspostava privatnih medija u Hrvatskoj. U kontekstu radija bila je riječ o zakonu kojim se uspostavlja sustav koncesija (prava korištenja) radi- 
ofrekvencijskog spektra i institucija koje su za to bile zadužene. Prvi Zakon o telekomunikacijama usvojen je 1994. godine, ali je stupio na snagu sljedeće, 1995. Nositelj prvih javnih natječaja za dodjelu koncesija za radijsko emitiranje bilo je Ministarstvo pomorstva, prometa i veza $\mathrm{RH}$.

Danas hrvatski radijski krajolik čine 143 koncesionara za emitiranje radijskog programa, različitih dosega čujnosti i programskih usmjerenja te Hrvatski radio s 11 programskih kanala, u sastavu Hrvatske radiotelevizije, jedinoga javnoga medijskoga servisa u RH. (AEM, Radijski nakladnici) Među koncesionarima je svega osam neprofitnog usmjerenja, dok su svi drugi uglavnom trgovačka društva u isključivom ili miješanom (privatno-javnom) vlasništvu. Gledano po razinama emitiranja, najbrojniji su radiji lokalne čujnosti (područje općina i gradova) kojih je 86. Tri radija imaju nacionalnu koncesiju, dok su preostali županijskog dosega. Zbog izraženih vlasničkih i programskih razlika, a osobito zbog zaštićenoga tržišnog položaja i načina prihodovanja, Hrvatski radio nalazi se na suprotnom kraju toga radijskog spektra.

Rad donosi pregled ključnih institucija i dosadašnje legislative čijim je djelovanjem izravno oblikovana današnja radiodifuzna slika Republike Hrvatske.

\section{HRVATSKA MEDIJSKA POLITIKA: INSTITUCIJE, ZAKONI I REGULATORI}

Sve europske zemlje imaju medijsku politiku, piše Zrinjka Peruško (1999: 87), bilo eksplicitnu (zakonodavstvo, institucije i mjere) ili implicitnu, koja počiva na konsenzusu glede očekivanja funkcioniranja medija u društvu.

U pozadini medijskih politika nalaze se neka, često implicitna, vjerovanja o ulozi medija i njihovu utjecaju na društvo. Te pretpostavke, svjesno ili nesvjesno, oblikuju normativna rješenja u medijskom sustavu i definiraju ciljeve, mjere i aktivnosti koje država poduzima [...] Takve strategije obično pretpostavljaju postojanje svojevrsnog društvenog konsenzusa oko očekivane ili poželjne uloge medija u društvu. Taj konsenzus možemo nazvati društvenom normativnom medijskom teorijom koja uključuje skup pretpostavki, vjerovanja, očekivanja ili bojazni što ih o medijima ili od medija, ima pojedino društvo. (Peruško, 1999:87).

Tragom eksplicitne medijske politike Vesna Alaburić (2000: 66-7) smatra da je pravo neophodan i nužan, ali ne i dovoljan, uvjet za slobodno i odgovorno funkcioniranje medija jer „bez demokratskog političkog okruženja nema ni slobodnih i demokratskih, neovisnih medija."

Medijska se politika svakako očituje u donošenju i poboljšanju zakona i propisa, kao i u uspostavi i organizaciji djelovanja različitih državnih i paradržavnih organizacija (agencija) te nadgledanju djelatnosti medija (regulator), navodi Nada Švob Đokić (2012: 5). Ključni je čimbenik sama država, posebice Ministarstvo kulture koje bi trebalo utjecati na sve aspekte organizacije i funkcioniranja medija. Švob Đokić smatra da u vrijeme nastanka 
njezina teksta Ministarstvo „ne raspolaže djelatnicima koji su profesionalno osposobljeni za praćenje medija“ te da državna administracija „nije uspješan koordinator aktivnosti za koje je odgovorna“ stoga što "lako podliježe političkim i ekonomskim pritiscima i slijedi posebne (ne-medijske) interese."

Rasprave o propisima i zakonima koji kreiraju medijsku politiku rijetke su i nemaju značajniji utjecaj na formuliranje zakona.[...] Poveznica koja nedostaje u procesima formuliranja i interpretacije medijske politike je organizirano i zainteresirano civilno društvo. Nedostaje vjerodostojan analitički uvid u razvoj medija i u provođenje medijske politike. (Švob Đokić, 2012: 5).

U kontekstu javnih politika, medijska politika jedna je od (brojnih) javnih politika čije „konce“ drži (ili ne drži) svaka vlast, odnosno ono za što Thomas R. Dye (1987: 2) jednostavno kaže: „Javna politika je sve ono što vlada odabere da će učiniti ili da neće učiniti“.

Ipak, vlast ima ključnu ulogu u konstituciji javnih politika. Ako 'nešto' nije potencijalno pitanje koje se postavlja vlasti, onda to nije javna politika. Vlada je najznačajniji policy akter, a njezino je djelovanje ključno u kreiranju javnih politika. Javne politike stoga se određuju kao skup odluka i aktivnosti vlade. (Petek, 2012: 41).

Prema taksonomiji javnih politika Hugha Compstona (2004: 9-10), učinjenoj na primjerima Velike Britanije, Francuske i Njemačke, medijska se politika nalazi u području posebnih sektorskih politika. Uloga medija u društvu i danas je sporna, piše lan Bartle (2004: 252) jer mediji

mogu biti društvena obrazovna i kulturna snaga, podjednako kao što mogu, osobito zbog svog komercijalnog usmjerenja, postati i destruktivni. [...] Mogu biti zagovornici slobode govora i medijskog pluralizma, ali i sredstvo za širenje propagande. Upravo zbog svoje visoke politiziranosti, medijska politika je posebno područje javnih politika. (Bartle, 2004: 252).

Analiza hrvatskih javnih politika Ane Petek (2012) uzela je u obzir samo politike čija se koherentnost očituje kroz isključivu nadležnost jednog ministarstva, pri čemu zamjećuje da se nekoliko javnih politika "rotira“ kroz više ministarstva. Riječ je o znanosti, tehnološkom razvoju, obrazovanju, medijima, kulturi i sportu.

Nalaze koherentnosti hrvatske medijske politike kao i eksplicitnih mjera tijekom proteklih 30-ak godina samostalne $\mathrm{RH}$, donosi tablica 1 . Tu treba naglasiti da se u području izvaninstitucijskoga sudjelovanja nalaze još brojni akteri, počevši od strukovnih i interesnih udruženja, preko udruga civilnog društva i građanskih inicijativa do akademske zajednice, tvrtki za zaštitu autorskih prava itd. Međutim, tablica 1 donosi samo institucijske aktere (ministarstva, državna tijela, regulatore) i legislativu. 
Tablica 1: Akteri i mjere hrvatske medijske politike od 1990. do 2020.

\section{Institucije}

Ministarstvo informiranja (1990. - 1992.)

Republički organ uprave nadležan za informiranje (1992. - 1996., tiskovine)

Državno tijelo za područje javnog priopćavanja (1996. - 2000., tiskovine)

Ministarstvo PPiV (1994. - 2000., radiji i televizije)

Ministarstvo kulture (od 2000. do danas, svi mediji)

Zakoni

Zakon o javnom informiranju (1992. - 1996.)

Zakon o javnom priopćavanju (1996. - 2003., dvije izmjene/dopune)

Zakon o medijima (od 2003. do danas, dvije izmjene i dopune)

Zakon o telekomunikacijama (1994.; 1999. do 2003., osam izmjena/dopuna/ispravaka)

Zakon o elektroničkim medijima (2003.; 2009. do danas, šest izmjena/dopuna)

\section{Regulatori}

Hrvatski zavod za telekomunikacije (1999. - 2003., teh. i administr. poslovi za el. medije)

Agencija za telekomunikacije (2003. - 2007., teh. i administr. poslovi za el. medije)

Agencija za elektroničke medije (od 2007. do danas, radiji, televizije i e-publikacije)

Izvršna tijela

Vijeće za slobodu javnog informiranja (1992., koregulatorno tijelo, nije zaživjelo)

Vijeće za telekomunikacije (1994. - 1999., radiji i televizije)

Vijeće za radio i televiziju (1999. - 2003., radiji i televizije)

Vijeće za elektroničke medije (od 2003. do danas, radiji, televizije i e-publikacije)

Izvor: Autorica

Medijima se u ratnim godinama kratko bavilo Ministarstvo informiranja (od svibnja 1990. do kolovoza 1992.), a potom dolazi do razdvajanja: tiskom se počinju baviti za to zadužena "državna tijela", Ministarstvo pomorstva, prometa i veza (MPPiV). ${ }^{2}$ Jasna, ali i jedina, poveznica tog ministarstva i elektroničkih medija bila su tehnička i tehnološka pitanja emitiranja, odnosno način i uvjeti korištenja radiofrekvencijskog spektra. Pitanje programskih sadržaja koji su se trebali emitirati na „tehničko-tehnološkim podlogama“ bilo je prepušteno novoosnovanom tijelu pod imenom Vijeće za telekomunikacije. Prvi saziv tog Vijeća činilo je šest aktivnih političara, jedan svećenik i dva sveučilišna nastavnika (Odluka o ..., NN 80/1994). Predsjedavao mu je aktualni ministar pomorstva, prometa i veza RH koji je bio "tvorac i autor" Zakona o telekomunikacijama (Mudrinić, 1997: 40). Jasna povezanost aktualne politike i članstva u Vijeću potvrđuje "različito razumijevanje demokracije“ budući da su "frekvencije kao i sami mediji smatrani dijelom državnog suvereniteta." (Peruško, 1999: 244).

\footnotetext{
${ }^{1}$ Uobičajena pravna formulacija kojom se nastoje izbjeći promjene u nadležnostima unutar pojedinih sektora.

${ }^{2}$ Proširenje nadležnosti dotadašnjeg Ministarstva pomorstva na „promet i veze“, poklapa se s dolaskom novog ministra.
} 
Brojni prigovori na rad Vijeća, a osobito netransparentni kriteriji dodjela (ili nedodjela) koncesija, kulminirali su u studenom 1996. godine, kada je Vijeće odbilo produžiti koncesiju za emitiranje ondašnjem popularnom zagrebačkom Radiju 101, a što je za posljedicu imalo masovni protest na glavnom zagrebačkom trgu (Mučalo, 2010:318-19). Percepcija o „svemoći“ Vijeća (jer Zakon o telekomunikacijama nije predvidio mogućnost žalbe na njihove odluke) nije bila utemeljena, ali je bila razlogom zbog kojeg mnogi sudionici javnih natječaja najčešće nisu tražili pravnu zaštitu svojih prava (Alaburić, 1996).

Novi Zakon o telekomunikacijama iz 1999. označio je početak razdvajanja telekomunikacijskog i medijskog područja. Tehničko-administrativni poslovi ušli su u nadležnost novoosnovane Agencije za telekomunikacije, dok se medijskim sadržajima i dodjelom koncesija bavilo (novo) Vijeće za radio i televiziju (ZoT, 1999., čl. 74). Izrijekom su isključeni političari, dužnosnici i osobe profesionalno povezane s radijskom ili televizijskom djelatnošću.

Koherentnost hrvatske medijske politike počinje s prijelazom u 21. stoljeće, kad se Ministarstvo kulture RH javlja kao nositelj tzv. mini-medijske reforme i predlaže tri nova medijska zakona: Zakon o elektroničkim medijima, Zakon o medijima i Zakon o HRT-u. Istaknuta uloga institucije, angažman samog ministra, „paket" od tri zakona i nove mjere, pokazali su da se medijski sustav može osmišljeno razvijati. Vujićs (2003: 9) piše da su odabrali put u kojem je način donošenja gotovo isto toliko važan kao i sam zakon, a to je najšira javna rasprava kakvu, prema njegovim saznanjima, nije prošao niti jedan zakon u Hrvatskoj.

Zakon o elektroničkim medijima iz 2003. godine propisao je čitav niz novih mjera od čega ćemo ovdje izdvojiti: (a) uvrštenje elektroničkih publikacija kao treće vrste elektroničkih medija, (b) osnivanje profesionalnog Vijeća za elektroničke medije i (c) osnivanje Fonda za poticanje pluralizma i raznovrsnosti elektroničkih medija.

Uvrštavanje elektroničkih publikacija (e-publikacije) u obitelj elektroničkih medija (tradicionalni radiji i televizije) bilo je očekivano i logično uvažavanje ulaska u digitalno doba. Budućnost e-publikacija nije bila upitna, ali potraga VEM-a za optimalnom definicijom, evidencijom i poslovanjem „novih" medija, traje i danas.

Vijeće za elektroničke medije (VEM) postalo je profesionalno tijelo od sedam članova koje predlaže Vlada RH, a bira Hrvatski sabor. Mandati traju pet godina s mogućnošću jednog produljenja. Tako je i danas. Predsjednik VEM-a ujedno je i ravnatelj Agencije za elektroničke medije (osnovana 2007.), čime je završen proces uspostave prvoga samostalnog medijskog regulatora u Hrvatskoj.

Fond za poticanje pluralizma i raznovrsnosti elektroničkih medija (Fond za pluralizam) zamišljen je kao proračunski fond koji se i danas puni izdvajanjem $3 \%$ ukupnoga godišnjeg iznosa prikupljenog na ime HRT-pristojbe. Osnivanjem Fonda završena je višegodišnja rasprava o pravu koncesionara na dio "javnog“ novca. Riječ je o značajnim iznosima ${ }^{4}$

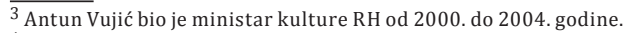

${ }^{4}$ Fond je od 2008. godine, u prosjeku, raspolagao s oko 4,2 milijuna eura.
} 
koje je VEM, putem javnih natječaja, trebao dodijeliti radijima i televizijama. Zabranu natjecanja imali su samo oni s nacionalnom koncesijom. Potpore su imale za cilj novčano poduprijeti produkciju sadržaja od javnog ${ }^{5}$ interesa. Prva su sredstva dodijeljena 2005. u omjeru pola radijima, pola televizijama. Tijekom sljedećih 25 godina radiji i televizije (mahom svi komercijalnog usmjerenja) dobivali su oko $93 \%$ fondovskog novca (Mučalo, 2018). Tako je i danas.

Peruško i dr. (2011: 173) smatraju da su se hrvatski medijski sustav i medijska politika 2009. godine „ljuljali na neoliberalnoj oštrici“ pri čemu je „pretegnula strana privatnih i partikularnih umjesto javnog interesa".

Poznato je i dokumentirano da se medijski sustavi razvijaju pod društvenim utjecajem, ponajprije putem medijskih politika, ali i javnih očekivanja. Također je potvrđeno da se u onim zemljama u kojima je država zakonodavnim medijskim okvirom prestala inzistirati na raznolikosti i pluralizmu sadržaja i medijskih izvora, on ubrzo smanjen pod nemilosrdnim utjecajem tržišnog spajanja i rasta medijskih industrija. (Peruško i dr., 2011:174).

Obilni iznosi javnog novca kojim su financirani komercijalni mediji u privatnom vlasništvu nametnuli su pitanja zašto se ne razvijaju i druge vrste medija, primjerice neprofitni ili lokalni javni mediji. Međutim, kako za te vrste medija zapravo nije bilo osobitog interesa, a elektroničke publikacije još nisu bile ni u tekstu Zakona o telekomunikacijama, povremena propitivanja „igranja na jednu kartu“ nisu imala posebnog odjeka u javnosti. Drugačije rečeno, broj komercijalnih medija koji su koristili Fond bio je toliko velik, a posljedično i utjecajan, da nikomu od njih nije bilo u interesu podupirati razvoj konkurencije. Jedini kojima je razvoj alternative bio u interesu bila je hrvatska javnost o čijem je pravu na informiranje trebala skrbiti državna vlast. Kako je 2015. godine izgledao medijski prostor Hrvatske, najbolje opisuje uvodni dio Nacionalnog izvještaja o medijima iz 2015. godine:

Popis kriznih žarišta već tada je sadržavao dugotrajne učinke komercijalizacije i koncentracije medija, gubitak i nesigurnost radnih mjesta novinarki i novinara izloženih prijetnjama, tužbama, pritiscima, pa čaki nasilju, nastavak erozije ugleda i progresiju sumnji na političku pristranost javnih medija, probleme lokalnog informiranja i nezavisne medije uvijek na rubu opstanka. Te godine je, u neprekinutom nizu ugašenih medija, još stotinjak medijskih radnika ostalo bez posla kada je prestao izlaziti Vjesnik, kulturna institucija sa (!) tradicijom dugom 72 godine. Prosvjedi su doveli do smjene još jedne uprave HRT-a, a novinski izdavači su zatražili da im država ponovno pomogne, još jednim sniženjem stope PDV-a... (Ministarstvo kulture RH, 2015: 2).

Bila je riječ o prvom institucijskom pokušaju analize domaćega medijskog prostora koji je bio motiviran potrebom rješavanja nagomilanih problema svih hrvatskih medija, ali i izradom medijske strategije. Pratilo ga je 12 radnih materijala koji danas predstavljaju jedinstven pregled zatečenog stanja toga vremena po vrstama medija. Rezultat analize bio je „Nacrt prijedloga medijske politike RH do 2020. godine“ (Ministarstvo kulture, 2015a). Bila je riječ o obimnom dokumentu kojem je predstojala javna rasprava, ali je proces $u$ cijelosti prekinut zbog ponovne smjene stranke na vlasti. Naime, nakon parlamentarnih izbora u studenome 2015., poziciju vodeće stranke ponovno je zauzeo HDZ, a novoizabra-

\footnotetext{
${ }^{5}$ Informiranje, programi za manjine, sadržaji namijenjeni područjima posebne državne skrbi, kultura, obrazovanje, znanost i umjetnost. Analiza trošenja prvi je put provedena 2014. godine, drugi put 2018. godine.
} 
ni ministar kulture u toj „kratkoj“ Vladi RH (od siječnja 2016. do listopada 2016.) zaustavio je rad na Nacrtu.

Pitanje medijske politike i medijske strategije ponovno je aktualizirano u mandatu nove, 14. Vlade RH (početak u listopadu 2016. godine) koja u svom Programu (za mandat od 2016. do 2020.), između ostalog, spominje i medijsku politiku koja potiče pluralizam, profesionalnost i raznolikost medija uz poštivanje medijskih sloboda.

Vlada će donijeti sveobuhvatnu medijsku strategiju koja će uključiti zakonodavne, medijske, društvene i kulturološke nužnosti jednoga zreloga demokratskog društva, uvažavajući u svakom trenutku neospornu važnost i ulogu medija, te na temelju nje aktualizirati paket medijskih zakona. Medijska strategija utvrdit će prioritete razvoja medijske politike i medijskog zakonodavstva, uzimajući u obzir tehnološke promjene te najavljene revizije europske pravne stečevine uključujući razvoj zajedničkog digitalnog tržišta EU, (Vlada RH, Program... 2016-2020, str. 33-34).

Međutim, tema medijske strategije u javnosti se dosad nije posebno aktualizirala. Centar za medijski pluralizam i slobodu medija (The Centre for Media Pluralism and Media Freedom, CMPF) svoje izvješće za 2017. godinu zaključio je riječima:

U 2017. godini nije bilo promjene politike ili zakona u medijskom sektoru. Nedostatak akcije pogoršao je mnoge sistemske probleme koji su se očitovali u posljednjih nekoliko godina. Oni uključuju loše radne uvjete za novinare, nedovoljnu širokopojasnu pokrivenost i nevoljkost državnih vlasti da pravovremeno omoguće zatraženi pristup informacijama. Među najproblematičnija područja spadaju komercijalni i vlasnički utjecaj na uređivački sadržaj, kao i loša reguliranje vlasništva i konkurencije između medija, kontinuirani politički pritisci na javni RTV servis, pristup medijima manjinama, neriješen pravni i financijski status neprofitne organizacije i mediji u zajednici, te nedostatak sveobuhvatne nacionalne strategije za medijsku pismenost, (CMPF, 2018: 11).

Usprkos najavama i obećanjima, pune tri godine te Vlade za domaći medijski sustav zapravo je učinjeno malo. Tek u veljači 2020. godine (u vrijeme nastanka ovog teksta) u javnu raspravu ušao je novi Zakon o elektroničkim medijima.

\section{KOMERCIJALNI FM RADIO U HRVATSKOJ: IDENTITET I VJERODOSTOJNOST}

Dva ZEM-a (iz 2003. i 2009.) obvezuju koncesionare na raznovrsnost sadržaja bez isticanja programskih mjerila. Međutim, informativni i oglašivački sadržaji imali su mjerila (kvote, minutažu, udio). Radijski koncesionari bili su obvezni najmanje $10 \%$ (za regionalnu razinu) odnosno 20 \% (za lokalnu razinu) tjednog programa posvetiti regionalnim i lokalnim vijestima i obavijestima. Nacionalna koncesija obvezivala je na informativni program $\mathrm{u}$ trajanju od najmanje 30 minuta, s informativnom emisijom u trajanju od najmanje 20 minuta. (ZEM, 2003, čl. 22).

Činjenica je da programskog nadzora u smislu monitoringa emitiranih sadržaja deset godina uopće nije bilo (osim u tehnološkim pitanjima). Programski nadzor počeo je osnivanjem AEM-a (2007) posrednim (snimanje programa) i neposrednim načinom (odlazak 
na teren). Kako se zaista odvijaju spomenuti nadzori, tko ih obavlja i na temelju kojih kriterija, teško je reći.

Pojava specijaliziranih (vjerskih, sportskih, glazbenih) programa nije bila posebno nova, dok su formatirani radiji ${ }^{6}$ doživljeni kao apsolutna modernizacija i iskorak k digitalnom dobu. Implementacija „formata“ odvijala se isključivo na privatnim komercijalnim radijima. Istraživanja o otpuštanju radijskih djelatnika nema, a dio je ionako radio na temelju ugovora (ili bez njega). Međutim, o teškoj situaciji na radijima osobito u vrijeme velike gospodarske stagnacije (od 2008. do 2016.) svjedoče podatci da je „zbog nemogućnosti ostvarivanja koncesionarskih prava i obveza" (što se ponajprije odnosi na plaćanja) tijekom 2013. i 2014. godine od emitiranja odustalo šest, odnosno pet FM radija, svi lokalne važnosti (AEM, Izvješća o radu, 2013; 2014).

Međutim, u to je vrijeme radio i dalje uživao povjerenje javnosti, osobito zbog svoje suzdržanosti prema „žutilu“ i „crnilu“ (Mučalo, 2010a: 88). Deset godina poslije pokazalo se da

veći broj građana RH ima malo ili uopće nema povjerenja u lokalne elektroničke medije.[...] Osnovni razlozi nepovjerenja u lokalne medije mogu se pronaći u njihovoj ovisnosti od političkih centara moći (!) $i$ njihovom (!) prilagođavanju političkim okolnostima te u nedostatku vjerodostojnosti koja se doživljava kao nusprodukt političke ovisnosti, (AEM, 2018: 75).

Još od samog početka uvođenja tržišta jedan od temeljnih problema bila je neravnopravna tržišna utakmica. U analognoj tehnologiji uvijek postoje "mali“, odnosno lokalni radiji (općina, grad) i „veliki“ (županija, regija, država). Očekivano, veći i snažniji signalom uvijek „pokrivaju“ manje, ali radio županijske razine može emitirati na gospodarski nerazvijenijem području od grada u kojem emitira lokalni radio. Dopuštanjem umrežavanja lokalnih radija (ZEM, 2003, čl. 35) i osnivanjem Fonda za pluralizam činilo se da je zakonodavac prepoznao probleme "lokalaca“ i da im želi pomoći da ih prebrode. Međutim, Fond su pod istim uvjetima nastavili koristiti svi, veliki i mali radiji.

Neprofitno radijsko usmjerenje, kao što samo programsko usmjerenje naglašava, nije radijski program namijenjen ostvarivanju dobiti. Međutim, to ne znači da nema zainteresiranih, a možda bi ih bilo i više da su takvi radiji, upravo zbog svoje specifičnosti, bili posebno tretirani. Činjenica je da nadležne institucije nisu pokazale nikakvo razumijevanje niti angažman. Tijekom 2010. počela su emitirati još tri neprofitna FM radija i to UNIDU (studentski radio Sveučilišta u Dubrovniku), Radio cvrčak ${ }^{7}$ (osnovna škola u Starim Mikanovcima) i Radio Sunce (Županijska liga za borbu protiv raka) u Splitu. „Nacionalna strategija stvaranja poticajnog okruženja za razvoj civilnog društva od 2012. do 2016. godine" još je 2012. upozorila na zanemarenost neprofitnog sektora, preporučila bolju zakonsku definiciju i traženje novih modela financiranja. „Posebna pažnja“ zatražena je za ponuditelje projekata neprofitne televizije i neprofitnog radija (Vlada RH, 2012: 39-40). Međutim,

\footnotetext{
${ }^{6}$ Formatirani radio obilježavaju precizno raspoređeni sadržaji (tzv. sat), tematski i vremensko strogo određeni. Glazbeni izbor (osnovni zvuk) oslonjen je na ograničeni izbor pjesama u dnevnoj rotaciji (ponavljanju). Govorni sadržaji svedeni su na kratke voditeljske ili DJ najave/informacije. Vlastitih informativnih sadržaja najčešće nema već ih se preuzima iz nekoga drugog izvora.

${ }^{7}$ Koncesija vraćena 2012. zbog nemogućnosti obavljanja djelatnosti.
} 
ništa se nije promijenilo. Danas neprofitni sektor radija i televizija broji osam neprofitnih radija i nijednu televiziju (u zemaljskom emitiranju).

Prvu analizu radijskog tržišta ${ }^{8}$ naručila je i objavila Agencija za elektroničke medije 2015. godine. Rezultati dotadašnje medijske politike prema radiju pokazali su se kroz mišljenja kako „radio nema karakteristiku koja ga izdvaja u odnosu na ostale medije [...] nije niti brži, niti vjerodostojniji niti neovisniji. Vjerodostojnost se veže uz televiziju, dok je brzina glavno svojstvo Interneta. (!).” (AEM, 2015: 64)

Opažanja o „uniformiranju“ programa proizlaze iz rezultata po kojima ni jedna radijska postaja (bez obzira na razinu koncesije ili područje) ne odskače od drugih i kako „većina postaja slijedi istu formu radijskog sadržaja - prevladavanje glazbenog programa i kratke i sažete informacije." (ibid: 65)

Neovisni stručnjaci (fokus grupa) smatraju da slušateljima treba ponuditi „više govornog sadržaja, posebice edukativnog, jer je nedovoljna zastupljenost govornog sadržaja jedan od nedostataka trenutnog radijskog programa.". Podjednako tako, izraženo je i nezadovoljstvo s informativnim programima koje ocjenjuju "oskudnim i istim na svim radijskim postajama. To je rezultat toga što većina najslušanijih radio postaja ne proizvodi vlastiti informativni program već prenosi informativni program Media servisa“ (ibid.).

Pitanje informativnog programa (vijesti i središnje informativne emisije) problematizira se još od samih početaka radijskog poduzetništva u Hrvatskoj. Usprkos propisanim obvezama (programskim kvotama) o čemu je već bilo riječi, informativni sadržaji nisu bili uvjetovani vlastitom proizvodnjom. Moguće slučajno, ali ta „rupica“ u ZEM-u kolidirala je s osnivanjem Media servisa, prve agencije (d.o.o.) specijalizirane za proizvodnju te vrste radijskih sadržaja (Media servis). Danas ta tvrtka broji 47 registriranih „članica“, odnosno radijskih postaja koje na svojim frekvencijama dnevno emitiraju njihove "proizvode". Međutim, to nije i jedini primjer distribucije istih sadržaja. Slična „informativna koncentracija“ proizlazi i iz sporazuma HRT-a s HURIN-om, ${ }^{9}$ koji je sklopljen u siječnju 2019. godine (HRT, 2019). Članice HURIN-a (80-ak lokalnih FM radija) mogu bez naknade svakodnevno reemitirati Jutarnju kroniku HR1 ili dvije kratke emisije vijesti tijekom dana. Nikoga nije posebno zasmetala sličnost s vremenima kad je reemitiranje "državnog radija“ bilo obvezno jer je jamčilo političku „ispravnost“ informativnih sadržaja.

Potrebno se zapitati svjedočimo li „prepisivačkom novinarstvu“, odnosno legitimnoj distribuciji istih sadržaja na različitim medijima. Inače, pojam „prepisivačkog novinarstva“ pojavio se i u zadnjem dostupnom istraživanju ${ }^{10}$ o društvenom utjecaju Fonda za pluralizam pri čemu ga radijski stručnjaci"1 objašnjavaju razlozima „skupoće izlaska na teren“, (AEM, 2018: 80-81).

\footnotetext{
8 Istraživanje je provela agencija IPSOS. Korištene su kvantitativne (terenska anketa na uzorku od 1.920 ispitanika) i kvalitativne metode (20 dubinskih intervjua s pripadnicima radijske i opće stručne javnosti).

${ }^{9}$ Hrvatska udruga radijskih nakladnika (HURIN) utemeljena je 2002. godine kao pravna sljednica čitavoga niza raznih udruga koje su od 1964. godine objedinjavale lokalna glasila u Hrvatskoj.

${ }^{10}$ Naručila ga je Agencija za elektroničke medije, a provedeno je u periodu od listopada 2017. do svibnja 2018., posredstvom metode ankete, dubinskih intervjua i fokus grupa. Evaluacijom je obuhvaćen period od 2013. do 2015. i nakladnici koji su za to vrijeme bili korisnici sredstava Fonda.

${ }^{11}$ Riječ je o ispitanicima koji rade na radijskim postajama.
} 
Prema istraživanju medijskih navika u RH iz 2019., ${ }^{12}$ radio se s „osvojenih“ 9,8 \% povjerenja nalazi daleko iza interneta (56,6\%) i televizije (26,2 \%). (24sata i IPSOS, 2019: 7) Prema spomenutoj AEM-ovoj analizi, povjerenje prema lokalnim medijima ocijenjeno je „zabrinjavajućim" jer im vjeruje tek trećina ispitanika. Razlozi počivaju u percepciji povezanosti s „lokalnim političkim i ekonomskim centrima moći“, "sprezi s nekom političkom opcijom" ili jednostavno vlasniku medija odnosno „lokalnom poduzetniku koji je povezan sa (!) nekom političkom opcijom", (AEM, 2018: 100-108).

\section{DIGITALNI RADIO: DAB+}

Digitalni radijski signal nije neka posebno nova tehnologija. DAB (digital audio broadcasting) je osmišljen potkaj 20. stoljeća, a 2007. unaprijeđen u verziju nazvanu DAB+. lako je i dalje riječ o zemaljskoj distribuciji, DAB nudi bitno veći broj distribucijskih kanala od standardnog FM-a, s mogućnošću dodatnih multimedijskih (tekstualnih, grafičkih, slikovnih, video) sadržaja. Među europskim zemljama, DAB je u cijelosti prihvatila samo Norveška koja ga je u siječnju 2017. počela sustavno uključivati uz podjednako sustavno, isključivanje dotadašnje FM mreže (od nacionalne prema nižim razinama). Odluka je ponajprije bila uvjetovana reljefom zemlje (fjordovima, otocima, razlikama u nadmorskoj visini) jer je infrastruktura potrebna za kvalitetan FM signal ipak znatno skuplja (veći broj odašiljača i repetitora) od one za DAB+.

Koliko je EU (ne)zainteresirana za implementaciju DAB-a, govori i podatak da niti jedna njezina država članica dosad nije napravila iskorak na tragu norveškog primjera. Naprotiv, time se aktivno bave zemlje koje nisu dio EU poput Norveške i Švicarske, a donekle i Velika Britanija koja je otišla iz Unije. Razlozi zbog kojih EU sporo implementira DAB (za razliku od digitalne televizije) mogu biti svakojaki, od motivacije (zašto mijenjati tehnologiju koja dobro služi), preko tehničkih (uštede u MHz bitno su manje od onih kod TV) do nezainteresiranosti "glavnih igrača“, telekom operatera koje osobito ne zanimaju "pojasevi“ ispod $100 \mathrm{MHz}$ jer nisu prikladni za mobilnu telefoniju i podatkovne usluge.

Naravno da zemlje EU imaju DAB ili DAB+, ali još uvijek kao dodatnu platformu (uz FM) koju zainteresirani radiji (FM, web radiji) mogu, ali i ne moraju koristiti. Otud proizlaze i razlike $u$ "pokrivenosti“ državnih teritorija digitalnim radijskom signalom. Primjerice, Francuska ima pokrivenost od $23 \%$, Mađarska od $30 \%$, Španjolska oko 52 \%, Poljska oko 55 \%, Njemačka oko 97 \% itd., dok su Slovačka, Slovenija, Luksemburg, Rumunjska, Bugarska i Hrvatska tek počele uvoditi DAB. (WorldDAB, 2019)

Prvo je testno emitiranje na DAB+ platformi ${ }^{13}$ u Hrvatskoj počelo 20. studenog 2017. godine. Nakon konzultacija s HAKOM-om ${ }^{14}$ i OiV-om, ${ }^{15}$ Vijeće za elektroničke medije upu-

\footnotetext{
$\overline{12}$ Kvantitativno istraživanje kombiniranim metodama, na uzorku od 800 ispitanika, provedeno u ožujku 2019.

13 Uključeni su odašiljači Sljeme, Ivanščica, Mirkovica i Učka na području koje obuhvaća Grad Zagreb, Zagrebačku županiju, Krapinsko-zagorsku županiju, Varaždinsku županiju, Međimursku županiju, dio Karlovačke županije, dio Sisačko-moslavačke županije, Primorsko-goransku županiju i Istarsku županiju.

14 HAKOM je samostalna i neprofitna nacionalna regulatorna agencija za mrežne djelatnosti koju je osnovala Republika Hrvatska. Osnivačka prava ostvaruju Hrvatski sabor i Vlada RH.

15 Odašiljači i veze d.o.o. nastali su podjelom Javne ustanove HRT na Hrvatsku radioteleviziju i Odašiljače i veze d.o.o. Tvrtka je osnovana 16. travnja 2002. godine i u vlasništvu je Republike Hrvatske.
} 
tilo je javni poziv za iskazivanje interesa za digitalno eksperimentalno emitiranje radijskih kanala. Odabrano je 16 FM radija (od $25^{16}$ prijava), od čega 15 komercijalnih i jedan neprofitni internetski radio (AEM, 10. 10. 2017.). Pred njima je bila godina dana emitiranja u DAB+ tehnologiji pri čemu su predviđeni troškovi takva emitiranja iznosili oko 430 eura (oko 3.300,00 HRK za svaki mjesec emitiranja). Svi eventualni drugi troškovi bili su odgovornost samih radija, sudionika eksperimenta.

Drugi poziv zainteresiranima objavljen je u studenom 2018., ali je zbog malog odaziva (devet komercijalnih FM radija), ponovljen i u prosincu. Ugovor je na kraju potpisalo 14 zainteresiranih tvrtki među kojima su se prvi put pojavili i programi Hrvatskog radija (HR1 i HR2), odnosno Hrvatska radiotelevizija. Odašiljači i veze d.o.o. tim povodom na svojoj korporativnoj stranici pišu:

Pokretanje emitiranja u digitalnoj radiodifuziji ima za cilj popularizirati novu digitalnu radijsku platformu baziranu na DAB+ (Digital Audio Broadcasting) tehnologiji koja se već naveliko koristi u drugim državama i tako Hrvatsku pridružiti većini europskih zemalja u kojima je prisutan digitalni radio. Eksperimentalno odašiljanje u trajanju od godine dana poslužiti (!) će i kao priprema za komercijalno uvođenje digitalnog radija i tehnološko testiranje. Pokretanje DAB+ je za OIV i Hrvatsku novi izazov kojemu je cilj polučiti pozitivan odjek kod nakladnika i građana te popularizirati novu digitalnu radijsku platformu koja se već naveliko koristi u drugim državama, (OiV, 16. 11. 2018.).

Treći poziv objavljen je 5. studenog 2019. godine. Ugovori su sklopljeni desetak dana poslije i to s 20 zainteresiranih tvrtki. Međutim, zbog nepopunjenosti multipleksa mrežnog operatera, Vijeće je opet produljilo rok za iskazivanje interesa.

Javno dostupnih službenih informacija o zadovoljstvu onih koji su sudjelovali (ili još uvijek sudjeluju) u eksperimentalnom korištenju DAB+ tehnologije, nema. Korporacijske stranice OiV-a donose informacije tehničko-tehnološkog sadržaja u kojima se tumače ciljevi i vrijednost nove tehnologije, ali ne i objašnjenja što bi DAB+ donio „običnim“ slušateljima.

Medijska reprezentacija DAB+ tehnologije također je izuzetno manjkava. Nedvojbeno je riječ o zahtjevnom sadržaju koji, upravo zbog strukovne terminologije, znatno otežava novinarski posao. U pet godina (od 2015. do 2020.) na online medijima u Republici Hrvatskoj, objavljeno ${ }^{17}$ je svega 26 novinarskih tekstova o uvođenju DAB-a (tablica 2).

Tablica 2. DAB+ u online medijima u RH (2015. - 2020.)

\begin{tabular}{llllll} 
Godina objave & 2015. & 2016. & 2017. & 2018. & 2019. \\
Broj tekstova & 1 & 2 & 12 & 6 & 5 \\
\hline
\end{tabular}

Izvor: autorica

\footnotetext{
$\overline{16}$ Nakon uvida u financijske, tehničke i organizacijske uvjete, 18 podnositelja prijava potvrdilo je sudjelovanje, četiri se nisu očitovala o prihvaćanju uvjeta, dok su ih tri FM radija odbila prihvatiti.

17 Podatak je nalaz iz preliminarnog istraživanja kojeg je autorica teksta provela u siječnju 2020. godine, a koje zasad nije objavljeno.
} 
Objavljeni su na 17 portala, od čega je 19 općih i četiri specijalizirana (informatika, tehnologija i poslovni sadržaji). Najviše tekstova objavljeno je u drugoj polovini studenog 2017., odnosno nakon što je resorni ministar Oleg Butković "pustio“ digitalni signal s odašiljača na Sljemenu. Budući da je riječ o stvarnom početku DAB+ tehnologije u Hrvatskoj, bio je to događaj od posebne važnosti, pa je i očekivano dobro popraćen. Većina tekstova donosila je informacije o prednostima DAB-a, dok su svega dva donekle kritički progovorila o obvezama krajnjih korisnika. Naime, ključni preduvjet slušanja radijskog programa u $\mathrm{DAB}+$ tehnologiji je kompatibilni (digitalni) prijemnik.

DAB+ ni 2018. i 2019. nije imao intenzivniju medijsku pozornost. Tijekom 2018. godine evidentirano je šest tekstova od čega su tri donijela vijest o usvajanju Zakona o elektroničkim komunikacijama (European Electronic Communications Code, EECC ${ }^{18}$ ), odnosno obvezujućoj odluci prema kojoj svako vozilo koje zbog prodaje ili iznajmljivanja stiže na EU tržište od 21. prosinca 2020. mora imati prijamnik koji prima i reproducira digitalizirane radijske usluge iz digitalne zemaljske radijske radiodifuzije (Službeni list EU, 17. 12. 2018., čl. 113, st. 1: prilog XI). EECC se mora implementirati u nacionalna zakonodavstva svih država članica EU u roku od tri godine (do prosinca 2021.). Preostali su se tekstovi iz 2018. opet bavili prednostima DAB-a, ali ovaj put u odnosu na nakladnike (više kanala za nove nakladnike, povećanje slušanosti postojećih, manje smetnji, podrška tekstualnim i slikovnim prikazima itd.) i slušatelje (veći izbor programa, manje smetnji, obavijesti u hitnim situacijama). Aktualiziran je i doprinos turizmu stoga što uvođenje DAB-a omogućava kontinuitet signala svim turistima koji stižu u Hrvatsku s ugrađenim digitalnim prijamnikom u vozilima. Spomenuta je i mogućnost kreiranja potpuno novih „turističkih" kanala.

U 2019. opet nalazimo aktualiziranje odredbi o vozilima iz EECC-a, ali i informativne osvrte o DAB-u s Weekend Media Festivala u Rovinju. Naime, Odašiljači i veze d.o.o. te su godine predstavili DAB+ i HbbTV (Hybrid broadcast broadband TV) što je bio itekako dobar povod za aktualiziranje teme. Međutim, informacije se ponavljaju (nabrajanje prednosti za nakladnike i slušatelje, važnost približavanja RH europskim i svjetskim standardima) s tek ponekim novim podatkom kao što je, primjerice, informacija da DAB+ već "pokriva“ oko $70 \%$ državnog teritorija (Tomić, 21. 9. 2019.).

Informacija o zadovoljstvu radijskih postaja, sudionika DAB eksperimenta, nema. Službenih informacija o dosadašnjem tijeku eksperimentalnog emitiranja, također nema. Odašiljači i veze d.o.o. tek na upit ${ }^{19}$ odgovaraju kako glavne primjedbe nakladnika nisu tehničke prirode već im smeta nedostatak strategije o uvođenju digitalnog radija na razini države i nedostatak informacija o broju DAB+ prijemnika u Hrvatskoj.

Nedvojbeno je da se DAB+ u Hrvatskoj predstavio na manjkav, nejasan, pa i alarmantan način koji je navodio na pomisao o isključenju analogne mreže. Djeluje kao već viđena situacija u kojoj je smjer medijskog razvoja diktirala tehnologija (i ekonomske zakonitosti) dok je pitanje medijskih sadržaja u cijelosti ispušteno.

\footnotetext{
$\overline{18}$ EECC je stupio na snagu 20. prosinca 2018. godine i novi je pravni okvir za osiguravanje slobode pružanja elektroničkih komunikacijskih mreža i usluga (osobito korištenja $5 \mathrm{G}$ mreže).

${ }^{19}$ Iz odgovora na pitanja koje je autorica rada uputila OiV-u u prosincu 2019.
} 


\section{ZAKLJUČAK}

Ovim se radom otvara pitanje zašto su komercijalni FM radiji u Hrvatskoj dominantan model emitiranja radijskog programa i kako se dogodio njihov monopolizam. Naime, uvažavanje pluralnosti i raznovrsnosti medija kao standarda svakoga demokratskoga medijskoga sustava, u Hrvatskoj je donijelo upravo suprotan učinak: 25 godina od uspostave medijskog tržišta evidentan je razvoj samo komercijalnih radija u privatnom vlasništvu. Jesu li institucijski akteri hrvatske medijske politike propustili uočiti tu pojavu ili se njome ne žele baviti?

Izvjesno je da su komercijalni radiji u privatnom vlasništvu najprisutniji model emitiranja u većini razvijenih zemalja. Međutim, podjednako je izvjesno da nisu i jedini unutar nekoga nacionalnoga medijskog krajolika. Načelo pluralnosti medija podrazumijeva da se mjerama medijske politike podupire razvoj i onih "različitih", zapravo drugačijih modela koje reprezentiraju neprofitni mediji, mediji zajednice i javni mediji lokalne važnosti. Upravo pluralnošću svojih medija, razvijene demokracije nastoje parirati izraženoj komercijalizaciji i trivijalizaciji medijskih sadržaja. U Hrvatskoj zasad imamo samo primjer komercijalnog monopola s jedne i javni medijski servis s druge strane.

Neprofitni radio, kao i radijske zajednice, zasigurno su „ranjiva grupa“ ukupne radiodifuzije. Nije privlačan investitorima koji za cilj imaju ostvarenje neke dobiti. Upravo stoga, aktivnu ulogu u njegovoj promociji zauzima sama država, najčešće putem proaktivnih mjera vlastite medijske politike. Međutim, to nije bio slučaj i s dosadašnjom hrvatskom medijskom politikom. Pokušaji afirmacije neprofitnih ili community modela u Hrvatskoj uglavnom su se odvijali u izvaninstitucijskome području i to bez osobitih rezultata. Tako je i danas. Stoga propitivanje monopolizma komercijalnih medija ujedno podrazumijeva i propitivanje (ne)uspješnosti hrvatske medijske politike, a posljedično i njezinu usklađenost s ciljevima Unije kojoj pripada.

Iskorak prema digitalnom radiju (DAB+) neće promijeniti postojeću radiodifuznu sliku Republike Hrvatske, kao ni omjer snaga u programskim usmjerenjima. Važnost mu zasad ponajprije počiva na uvrštenju Hrvatske u krug članica EU koje su počele s implementacijom digitalnog radija, dok o nekom posebno važnom (strateškom) utjecaju na postojeću radijsku sliku nema ni govora.

Još uvijek ima vremena za raspravu o željenoj medijskoj slici Hrvatske. Trebalo bi poći od početka i analizirati razloge koji su doveli do prevlasti komercijalnih radija, ali i drugih komercijalnih elektroničkih medija. Zasad se primjedbe uglavnom kreću u poznatom spektru koji čine nezainteresirane nadležne institucije, nedovoljna stručnost krovnog tijela i snažan utjecaj interesnih grupa. Aktualna domaća radijska slika zorno svjedoči o propustima aktera, medijskim zakonima i odlukama kojima se proteklih godina oblikovala hrvatska scena elektroničkih medija. 


\section{Literatura}

>AEM (2020) Radijski nakladnici. https://www.aem.hr/ (15.1. 2020.)

$>$ AEM (2020) Izvješća o radu. https://www.aem.hr/izvjesca-o-radu/ (15.1.2020.)

$>$ AEM (2017) Vijeće za elektroničke medije odabralo radijske postaje za digitalno eksperimentalno emitiranje. https://www.aem.hr/vijesti/vijece-za-elektronicke-medije-odabralo-radijske-postaje-zadigitalno-eksperimentalno-emitiranje/ (17.1.2020.)

$>$ AEM (2015) Analiza radijskog tržišta. https://www.aem.hr/istrazivanja-i-analize/ (11.1.2020.)

$>$ AEM (2018) Analiza društvenog utjecaja Fonda za pluralizam i raznovrsnost elektroničkih medija.

https://www.aem.hr/istrazivanja-i-analize/ (11.1.2020.)

>AEM (2019) Vijeće za elektroničke medije odabralo digitalne radije u Fazi IIl i produljilo javni poziv za prijave. https://www.aem.hr/nekategorizirano/vijece-za-elektronicke-medije-odabralo-digitalneradije-u-fazi-iii-i-produljivo-javni-poziv-za-prijave/ (26.1.2020.)

$>$ Alaburić, Vesna (1996) Zakonodavstvo i praksa. Erasmus 17: 7-10.

$>$ Alaburić, Vesna (2000) Pravo i pravne institucije u stvaranju neovisnih medija. Medijska istraživanja 6 (2): 65-68. Preuzeto s https://hrcak.srce.hr/26299

$>$ Bartle, Ian (2004) Media, str. 252-265, u: Compston, Hugh (ur.) Handbook of public policy in Europe. Britain, France and Germany. New York: Palgrave Macmillian. https://doi. org/10.1057/9780230522756_23.

>Bašić Hrvatin, Sandra i Petković, Brankica (2014) Regionalni pregled, str. 11-57, u: Leković, Saša (ur.) Značaj medijskog integriteta, Vraćanje medija i novinarstva u službu javnosti. Medijski opservatorij u jugoistočnoj Europi (SEE Media Obsrvatory) i Centar za istraživačko novinarstvo Zagreb.

>CMPF (2018) Media Pluralism Monitor 2017. Monitoring risks for media pluralism in EU and beyond. Country Report:Croatia. http://cmpf.eui.eu/wp-content/uploads/2018/11/Croatia_MPM2017_ country-report.pdf (15.1.2020.)

$>$ Compston, Hugh (2004) Introduction: the nature of public policy in Britain, France and Germany, str. 1-13, u: Compston, Hugh (ur.) Handbook of public policy in Europe. Britain, France and Germany. New York:Palgrave Macmillian.

>Dye, Thomas. R. (1987) Understanding Public Policy. New Jersey: Prentice Hall.

>HRT (2019) HRT i HURIN potpisali Sporazum o razmjeni i ustupanju najslušanijih emisija Informativnog programa HR-a. https://hrtprikazuje.hrt.hr/485663/hrt-i-hurin-potpisali-sporazum-o-razmjeni-iustupanju-najslusanijih-emisija-informativnog-programa-hrvatskog-radija (11.11. 2019.) >24 sata i IPSOS (2019) Medijske navike u Republici Hrvatskoj. https://showcase.24sata.hr/2019_ hosted_creatives/medijske-navike-hr-2019.pdf (20.1.2020)

>Media servis (2020) O nama. http://www.mediaservis.hr/index.php/o-nama (20.1.2020)

>Ministarstvo kulture RH (2015) Nacionalni izvještaj o medijima (2015). https://www.minkulture.hr/ default.aspx?id=12071 (11.1.2020.)

>Ministarstvo kulture RH (2015a) Nacrt prijedloga medijske politike RH do 2020. godine (2015). https://www.hnd.hr/medijska-strategija-donosimo-dokument-o-kojem-svi-znaju-sve-ali-ga-nisuprocitali (11.1.2020.)

>Mučalo, Marina (2002) Radio u Hrvatskoj. Zagreb: Fakultet političkih znanosti.

$>$ Mučalo, Marina (2010) Radio-medij 20. stoljeća. Zagreb: AGM.

$>$ Mučalo, Marina (2010a) Radio: medij neiskorištenog povjerenja. Medijske studije 1 (1-2): 78-90.

>Mučalo, Marina (2018) Javno financiranje elektroničkih medija u Republici Hrvatskoj, str. 30-67, u: Milojević, Ana i Veljanovski, Rade (ur.) Verodostojnost medija: odnos finansiranja i sadržaja. Beograd: Fakultet političkih nauka.

>Mudrinić, Ivica (1997) Medijski trenutak Hrvatske (s osvrtom na HRT), str.37-43, u: Novosel, Pavao (ur.) Trenutak hrvatske komunikacije. Zagreb: Fakultet političkih znanosti.

>Narodne novine Republike Hrvatske (1994) Odluka o imenovanju članova Vijeća za telekomunikacije. br. 80. (10.1.2020.)

>OiV (2018) Druga godina emitiranja DAB+ radija. https://www.oiv.hr/tvrtka/vijesti/vijest_ hr.aspx?id=2721 (10.1.2020.)

>Peruško, Zrinjka (1999) Demokracija i mediji. Zagreb: Barbat. 
PREGLEDNI RAD / DOI: https://doi.org/10.20901/ms.11.21.5 / PRIMLJENO: 27.2.2020.

>Peruško, Zrinjka; Perišin, Tena; Topić, Martina; Vilović, Gordana i Zgrabljić Rotar, Nada (2011) Hrvatski medijski sustav prema UNESCO-vim indikatorima medijskog razvoja. Biblioteka hrvatska politologija. Fakultet političkih znanosti: Zagreb.

$>$ Petek, Ana (2012) Što su hrvatske javne politike? Političke analize 3 (11): 37-45.

>Popović, Jasmina (2000) Nema slobodnih novinara. Medijska istraživanja 6 (2): 129-133.

>Službeni list Europske unije (2018) Zakon o elektroničkim komunikacijama. L321: 32-190. https:// eur-lex.europa.eu/legal-content/HR/TXT/?uri=OJ:L:2018:321:TOC (15.1.2020).

>Švob Đokić, Nada (2012) Prijedlozi za podršku slobodi i nezavisnosti medija u Hrvatskoj. Mediadem. http://www.eliamep.gr/mediadem/ (15.11.2019)

>Tomić, Dražen (2019) Stižu digitalni radio DAB+ i HbbTV interaktivna televizija. https://www. ictbusiness.info/telekomunikacije/stizu-digitalni-radio-dab-i-hbbtv-interaktivna-televizija (14.1.2020.)

>Vlada RH (2016) Program Vlade RH za mandat 2016. - 2020. https://vlada.gov.hr/kako-funkcioniravlada/program-vlade/11688 (28.11.2019.)

$>$ Vlada RH (2012) Nacionalna strategija stvaranja poticajnog okruženja za razvoj civilnog društva od 2012. do 2016. godine. http://www.krila.hr/UserDocsImages/ Nacionalna\%20strategija\%20FINAL.pdf (28.11.2019.)

$>$ Vujić, Antun (2003) Uvodna riječ, str. 7-12, u: Antolović, Jadran (ur.) Medijsko zakonodavstvo Republike Hrvatske. Zagreb: Ministarstvo kulture RH.

>Zakon o telekomunikacijama, Narodne novine RH, 53/1994 i 76/1999

>Zakon o elektroničkim medijima, Narodne novine RH, 122/2003 i 153/2009

>WorldDAB (2019) Countries. https://www.worlddab.org/countries (20.1.2020.) 


\section{COMMERCIAL FM RADIO IN THE CONTEXT OF CROATIA'S MEDIA POLICY}

\section{Marina Mučalo}

ABSTRACT Commercial private radios dominate the Croatian radio landscape. They have been evolving since the mid-1990s. In the last fifteen years they have been systematically financed by public funding, namely by the Fund for the Promotion of Pluralism and Diversity of Electronic Media. This paper problematizes Croatia's media policy, which, in the recent years, has completely neglected the development of non-profit and public service broadcasting, leaving the country's media development with market instruments and commercial content. Recent research shows that this type of radio is perceived as a monotonous musical scenery that loses listeners' trust. The paper raises a question of further development of the Croatian media system, with a prominent role for the institutions responsible for shaping it.

KEYWORDS

COMMERCIAL FM RADIO, MEDIA SYSTEM, MEDIA POLICY, CROATIA

Marina Mučalo :: Faculty of Political Science University of Zagreb :: marina.mucalo@fpzg.hr 